AUCES

\title{
IMPACT OF TECHNOLOGICALLY ENHANCED NATURALLY OCCURRING RADIOACTIVE MATERIALS (TE-NORM) IN OIL AND GAS INDUSTRY ON ENVIRONMENT
}

\author{
Ahmed Mohamed Ahmed Salama \\ ENVIRONMENTAL ENGINEERING DEPT. FACULTY OF ENGINEERING, HELWAN UNIVERSITY
}

ABSTRACT:

Naturally-occurring radioactive material (NORM) is the term used to describe materials containing radionuclides that exist in the natural environment. The radionuclides of interest include long-lived radionuclides such as uranium-238 (238U), uranium-235 (235U) and thorium-232 (232Th) and their radioactive decay products (such as isotopes of radium, radon, polonium, bismuth and lead), and individual long-lived radionuclides such aspotassium-40 (40K), rubidium-87 (87Rb) and indium-115 (115In). The parent radionuclides have decay times (half-lives) which are comparable with or larger than the age of the earth, so they have always been present in the earth's crust and within the tissues of all living species. Where materials contain radionuclides from the naturally occurring decay chains $(238 \mathrm{U}, 235 \mathrm{U}, 232 \mathrm{Th})$, the large number of radionuclides in each chain, and the resulting large range of physical and chemical properties of the individual radionuclides, means that there can be a highly variable degree of secular equilibrium between the individual members of the chains.

\section{(1)INTRODUCTION:}

Technologically enhanced naturally occurring radioactive material (TE-NORM)) and (or) enhanced potential for exposure to naturally occurring radioactive materials in products, byproducts, residues and wastes. Such activities may include, for instance, the mining and processing of ores, the combustion of fossil fuels, or the production of natural gas and oil. If these residues containing naturally occurring radionuclides are not managed properly and safely, contamination over large areas is possible given the large quantities of such residues.

\section{(1.1)The origins of Naturally Occurring}

\section{Radioactive Material (NORM)}

Radioactive materials such as Uranium and Thorium were incorp- orated in the Earth's crust when it was formed; these normally exist at trace (parts per million - ppm) concentrations in rock formations. Decay of these unstable radioactive elements produces other radionuclides that, under certain conditions (dependent upon pressure, temperature, acidity etc.) in the subsurface environment are mobile and can be transported from the reservoir to the surface with the oil \& gas products being recovered .During the production process, NORM flows with the oil, gas and water mixture and accumulates in scale, sludge and scrapings. It can also form a thin film on the interior surfaces of gas processing equipment and vessels.

\section{(1.2)Types of radiation emitted by NORM}

There are three types of radiation emitted by NORM, namely;

- Alpha ( $\alpha)$ 
- Beta ( $\beta$ )

- Gamma $(\gamma)$

- Alpha particles are helium nuclei that are heavy and positively charged which causes them to lose their energy very quickly in matter. Thy can be stopped by a sheet of paper or the surface layer of your skin.

- Beta particles are much smaller and only have one (negative) charge, which causes them to interact more slowly with material. They are effectively stopped by thin layers of metal or plastic and considered hazardous only if a beta emitter source is ingested or inhaled.

- Gamma emitters are associated with alpha, beta decay and are a form of high energy electromagnetic radiation that interacts lightly with matter. Gamma rays are best shielded by thick Layers of lead or other dense materials and are considered as an external hazard to living tissues (i.e. the human body). Figure 1 details the penetrating power of ionizing radiation emitted from NORM radionuclides.

\section{(1.3) NORM in gas processing facilities}

Radon is a radioactive gas, which is present in varying degrees in natural gas in oil \& gas formations. In the absence of natural gas, radon Dissolves in the (light) hydrocarbon and aqueous phase. When produced with the oil and gas, radon will usually follow the gas stream. If the natural gas is fractionated, a disproportionately high Percentage of radon can concentrate in the propane streams and to a lesser degree in the ethane streams. Radon-222 produces, through natural decay, several radioactive nuclides (also known as radon progeny). Most radon progeny are shortlived, with the exception of Lead-210 and Polonium210, which have relatively long half- Lives of $\mathbf{2 2 . 6}$ years and 138 days respectively. Most of the radon decay products $(90-99 \%)$ are attached to ambient aerosols, airborne particulates or surfaces. This can result in forming thin radioactive films on the inner surfaces of gas processing Equipment such as scrubbers, Compressors, reflex pumps, control Valves and product lines. Fig 2 shows the oil and gas plant.

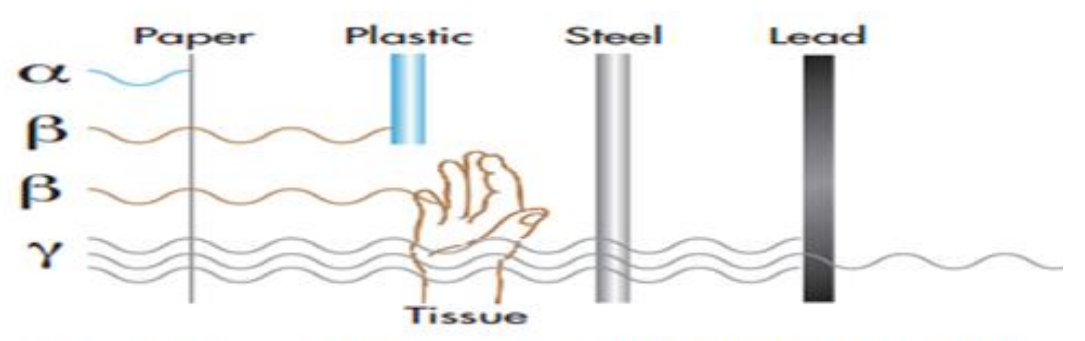

Figure 1 the penetrating power of ionizing radiation emitted from NORM radionuclides.

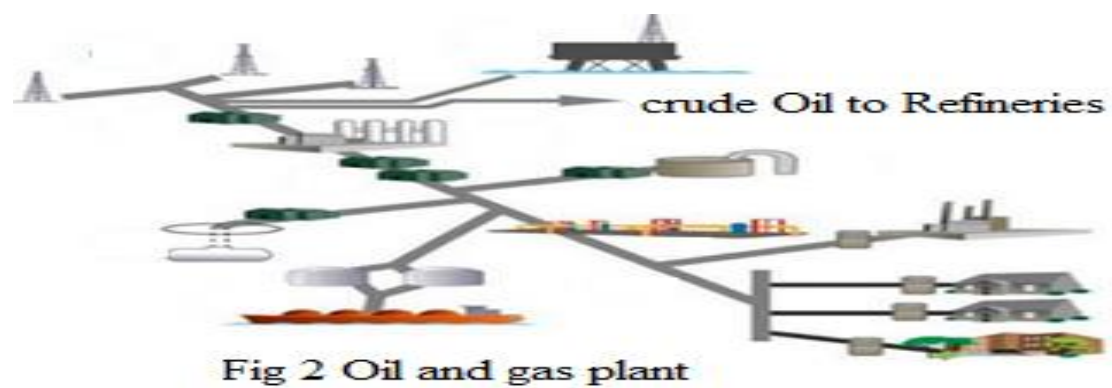




\section{(2)HEALTH HAZARDS OF NORM}

\section{(2.1) TYPES OF NORM EXPOSURE,}

\section{See Fig 3}

\section{(2.1.1) Irradiation-external}

Exposure where the source remains outside the body

\section{(2.1.2) Contamination}

Internal exposure where radioactive material is taken into the body via inhalation, ingestion or absorption there is a large body of scientific research and literature on the health effects of ionizing radiation exposure. The health effects associated with exposure to ionizing irradiation vary depending on the total amount of energy absorbed, the time period, the dose rate and the effects such as the development of certain forms of Associated with exposure to ionizing radiation

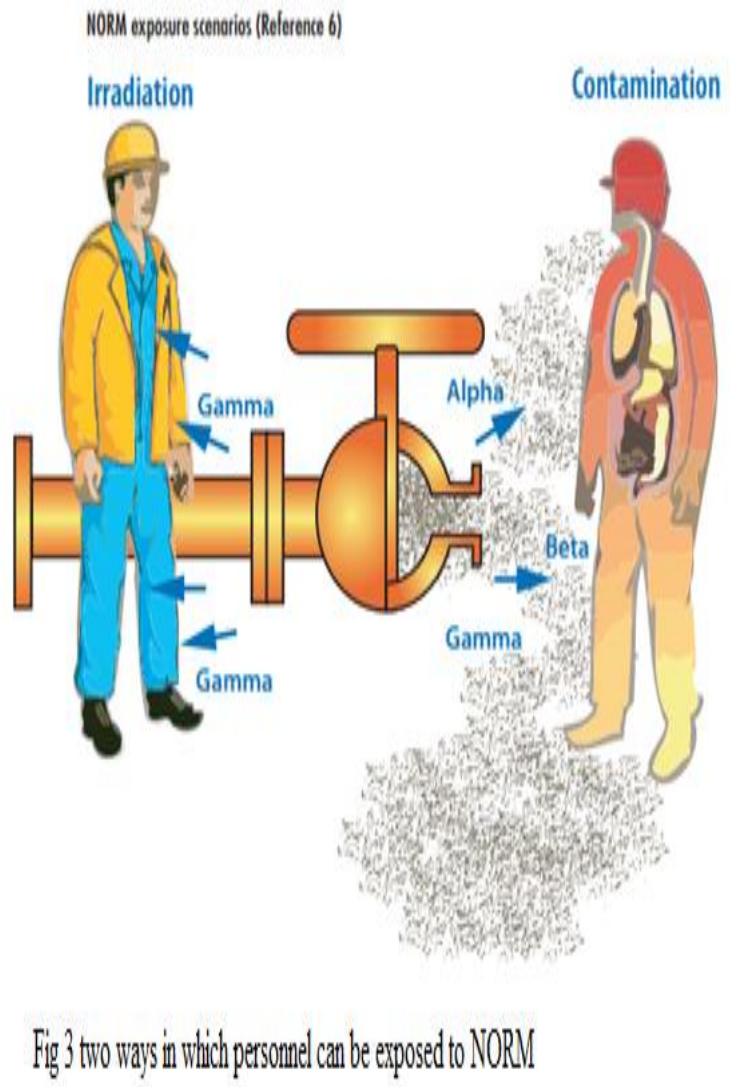

Particular organ exposed. A key consideration Related to NORM is that exposures are generally quite low and below established regulatory action levels. In some situations, exposure to low-level ionizing radiation may not result in any adverse health effects; hence the basis for developing regulatory health-based action levels. Exposure to NORM will not result in acute and severe effects similar to those effects associated with exposure to high radiation levels from man-made sources. Chronic Exposure to NORM above exposure limits for the general public or following inadequate safety precautions are typically delayed

Cancer. A variety of cancers has been including leukemia, and cancers of the lung, stomach, esophagus, bone, thyroid, and the brain and nervous system. It is important to understand that the potential health effects are strongly doserelated. In addition, radiation exposure is not associated with all forms of cancer. Medical surveillance for low-level radiation exposures is typically triggered by exceedance of an established regulatory action level. However, medical surveillance is an imperfect and non-specific tool. It is Duffel to fid medical tests that detect meaningful abnormal changes in a timely fashion. Most medical tests do not have high Sensitivity or specificity, i.e. the ability to correctly identify who has a problem (sensitivity-true positive) and who doesn't have a problem (specificity- true negative).

\section{(2.2)Radiation levels at the outside of}

\section{processing facilities}

The organ at risk for a particular radionuclide can depend on a number of factors. The organs Quoted in Table 1 assume that the nuclide is the only radionuclide Present. However, if the nuclide of interest forms inside the body as a 
result of radioactive decay, its impact can depend on the point where the decay takes place, particularly if the nuclide is short-lived. In some cases, particularly for beta emitting radionuclides such as $234 \mathrm{mPa}$ and the $\mathrm{Bi}$ isotopes, The internal dose contribution is negligible compared with the internal dose contributions from other nuclides. The radiological and physical properties and the organs potentially at risk for each of the Radionuclides in the $235 \mathrm{U}$ decay chain. The fractional abundance of $235 \mathrm{U}$ is very much less than that of $238 \mathrm{U}$, so that in Most situations the dose contribution from $235 \mathrm{U}$ and its decay products is much smaller than the contribution from $238 \mathrm{U}$ and its decay products. The radiological and physical properties and the organs potentially at risk for each of the radionuclides in the 232Th decay chain are summarized in Table1.

The physical and chemical properties of the radionuclides can have a strong Influence on their environmental behavior and resulting exposure Pathways.

For example, the isotopes of lead and polonium are volatile at temperatures commonly Encountered in smelters, blast furnaces and power Station furnaces. This means that these processes can release lead and polonium isotopes to the radiological and physical properties and organs potentially at risk for some single naturally occurring radionuclides.
NORM is widely distributed, and gives rise to a natural radiation back ground that varies by approximately two orders of magnitude over the Earth, and even more if localized mineral deposits are taken into account. This mean survey living Species is exposed to this radiation, and in most Situations this exposure is not amenable to control. There appears to be no scientific evidence relating general variations in this natural background to health effects atmosphere.

\section{(3) MANAGEMENT OF OIL-FIELD}

\section{NORM:}

(3.1) NORM may undergo some of the following stages depending on the type of waste and the strategy for its management:

-Pre-treatment is the initial step that occurs just after waste generation. It may involve collection, segregation, Chemical adjustment and Decontamination and may also include a period of interim storage. The aim of this step is to segregate waste into streams that will be managed in similar ways, and to isolate non-radioactive wastes or those materials that can be recycled.

-Treatment involves changing the characteristics of the waste by volume reduction, radionuclide removal or change of composition.

Table 1 : The important properties of the members of the 23 Th decay chain

\begin{tabular}{|c|c|c|c|c|}
\hline Nuclide & $\begin{array}{l}\text { Half-life (Chu } \\
\text { et al, 1999) }\end{array}$ & Form & $\begin{array}{l}\text { Principal } \\
\text { radiation }\end{array}$ & $\begin{array}{c}\text { Organ(s) potentially at } \\
\text { risk }\end{array}$ \\
\hline $232 \mathrm{Th}$ & $1.41 \times 10^{10} \mathrm{a}$ & solid & $\alpha, \beta, Y$ & $\begin{array}{l}\text { lung, skeleton, liver, } \\
\text { colon }\end{array}$ \\
\hline $228 \mathrm{Ra}$ & 5.75 a & solid & $\beta$ & lung, bone \\
\hline $228 \mathrm{AC}$ & $6.15 \mathrm{~h}$ & solid & $\beta, \gamma$ & \\
\hline $228 \mathrm{Th}$ & $1.91 \mathrm{a}$ & solid & $a$ & $\begin{array}{l}\text { lung, skeleton, liver, } \\
\text { colon }\end{array}$ \\
\hline $224 \mathrm{Ra}$ & $3.66 \mathrm{~d}$ & solid & $a, \gamma$ & lung, bone \\
\hline $220 \mathrm{Rn}$ & $55.6 \mathrm{~s}$ & gas & $a$ & lung \\
\hline $216 \mathrm{Po}$ & $0.145 \mathrm{~s}$ & solid & $a$ & liver \\
\hline $212 \mathrm{~Pb}$ & $10.6 \mathrm{~h}$ & solid & $\beta, Y$ & bone \\
\hline $212 \mathrm{Bi}$ & $60.6 \mathrm{~min}$ & solid & $\alpha, \beta, Y$ & \\
\hline 212 Po $(64 \%)$ & $2.99 \times 10^{-7} \mathrm{~s}$ & solid & $\alpha, \beta, \gamma$ & liver \\
\hline $208 \mathrm{~Pb}$ & Stable & solid & $\beta, Y$ & bone \\
\hline $208 \mathrm{Tl}(36 \%)$ & $3.053 \mathrm{~min}$ & solid & $\beta, Y$ & \\
\hline $208 \mathrm{~Pb}$ & Stable & solid & & \\
\hline
\end{tabular}




\section{Typical treatment operations include:}

- compaction of dry solid waste or incineration of solid or organic liquid wastes (volume reduction);

- filtration or ion exchange of liquid waste (radionuclide removal); and

- Precipitation or flocculation of chemical species (change of composition).

\section{-Conditioning}

Involves transforming radioactive waste into a form that is suitable for handling, transport, storage and disposal.

\begin{tabular}{|c|c|}
\hline Disposal method & Description \\
\hline Land spreading & $\begin{array}{l}\text { It involves disposal by spreading sludge and scale on the surface/ open lands } \\
\text { in an area where NORM was not originally present above background levels. }\end{array}$ \\
\hline $\begin{array}{l}\text { Land spreading with dilution } \\
\text { (land farming) }\end{array}$ & $\begin{array}{l}\text { Land spreading with dilution involves mixing of the applied NORM thoroughly } \\
\text { within the top } 8 \text { inch }(20.3 \mathrm{~cm}) \text { layer of soil using agricultural equipment in an } \\
\text { area where NORM was not originally present above background levels. }\end{array}$ \\
\hline Non-retrieved line (surface) pipe & $\begin{array}{l}\text { Buried line pipe used at a facility could be abandoned in place after being } \\
\text { flushed to remove any oil or gas present. }\end{array}$ \\
\hline Burial with unrestricted site use & $\begin{array}{l}\text { Burial with unrestricted site use involves burial of NORM with at least } 15 \text { feet } \\
(4.6 \mathrm{~m}) \text { of cover that is level with the surrounding terrain, minimizing erosion } \\
\text { potential. }\end{array}$ \\
\hline $\begin{array}{l}\text { Commercial oil industry waste } \\
\text { facility }\end{array}$ & $\begin{array}{l}\text { Disposal in a commercial oil industry waste facility assumes burial with other } \\
\text { oilfield wastes where NORM represents less than } 7 \% \text { of the total waste } \\
\text { volume. }\end{array}$ \\
\hline Commercial NORM waste facility & $\begin{array}{l}\text { A NORM waste disposal site is designed to contain NORM for long periods and } \\
\text { its control may revert to a national authority for permanent monitoring and } \\
\text { restricted future use after closure. }\end{array}$ \\
\hline $\begin{array}{l}\text { Commercial low level radioactive } \\
\text { waste facility }\end{array}$ & $\begin{array}{l}\text { A low-level radioactive waste disposal is defined and licensed under national } \\
\text { regulations with numerous protective features and restrictions. }\end{array}$ \\
\hline Plugged and abandoned well & Well abandonment operations provide an opportunity to dispose of NORM. \\
\hline $\begin{array}{l}\text { Well injection and hydraulic } \\
\text { fracturing }\end{array}$ & $\begin{array}{l}\text { Sludge and scale wastes could be injected or fractured into formations that } \\
\text { are isolated geologically and mechanically. }\end{array}$ \\
\hline Equipment release to smelter & $\begin{array}{l}\text { Smelting may be a viable option for NORM contaminated tubular and other } \\
\text { equipment. }\end{array}$ \\
\hline
\end{tabular}

TABLE 2 Description of disposal methods 
Storage may be used to make the next step in the management process more straightforward or to act as a buffer between or within steps. Waste might be stored for many years before it undergoes further processing and disposal. Some storage facilities are located within a nuclear power plant or a licensed disposal facility, others are separate facilities.

$$
\text { Retrieval involves recovering waste }
$$

packages from storage either for inspection, for disposal or for further storage in new facilities. Some storage facilities are designed so the equipment that deposits waste can be operated in reverse to retrieve waste packages. Others may need retrieval equipment to be installed.

Disposal occurs when packages of radioactive waste are deposited in a disposal facility, with no intention of retrieval. Disposal may also include discharging radioactive wastes such as liquid and gaseous effluent into the environment and transfer of wastes from one site to another.

\section{(3.2) NORM removal and disposal:}

The disposal methods for NORM waste used nowadays by the oil and gas industry can be subdivided into five categories: Land based management; Salt cavern disposal; offshore discharge; Land fill and Underground injection. Their characteristics are presented in the table 2 Description of disposal methods (OGP 2008) once formed, barite is a very insoluble mineral. One liter of water at the Earth's surface dissolves only

0.0025 grams of barite. Efficient removal of barite deposits from oil-field equipment requires special chemicals or vigorous mechanical methods. The process of barite removal and disposal is complicated by the need to minimize radiation dose to workers and the general public. Radiation exposure pathways include external gamma radiation (major), ingestion (minor), and inhalation of particulates and radon gas (major).

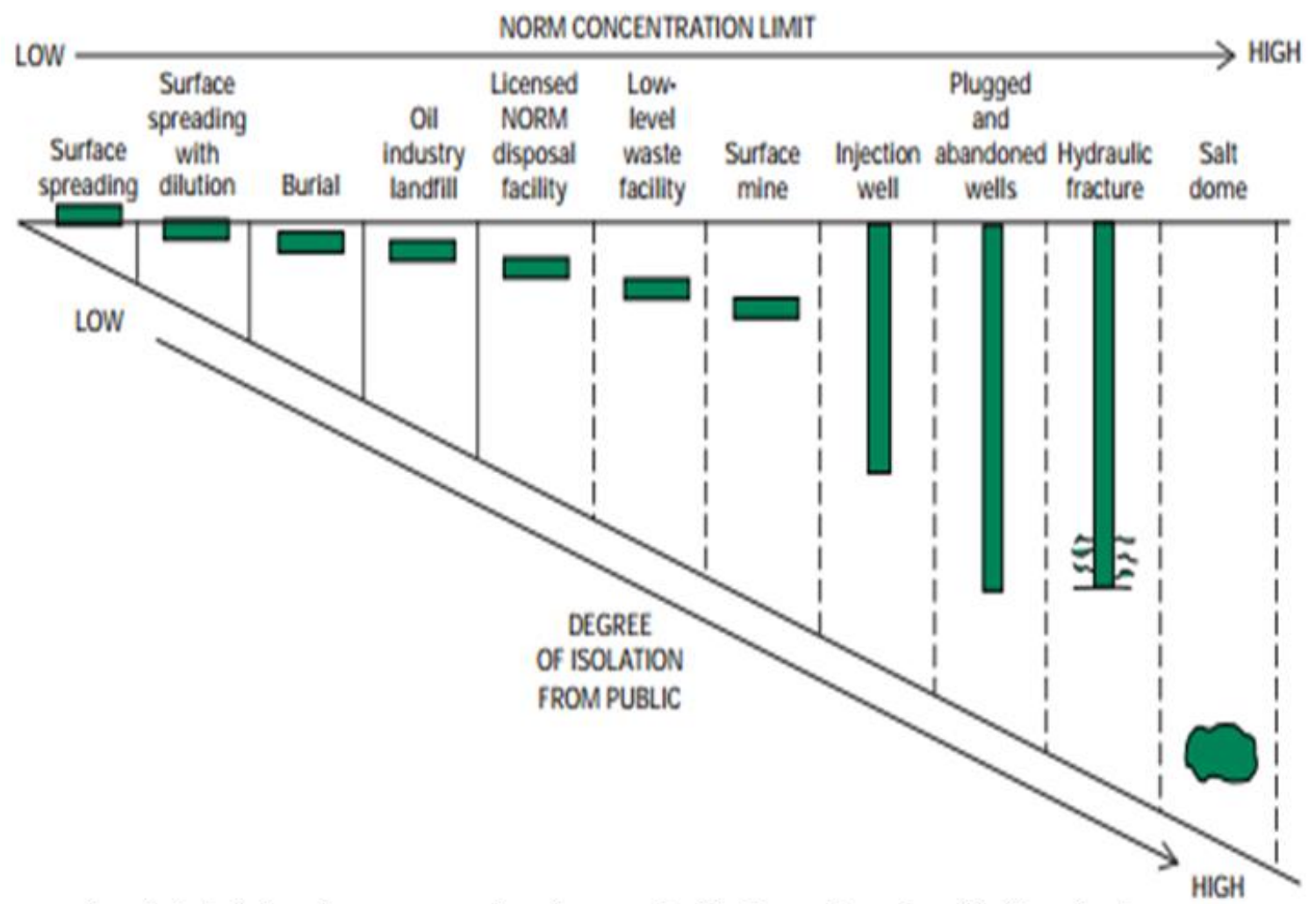

FIG 4 the relative isolation of NORM waste from the general public for a variety of possible disposal options 
Figure 4 illustrates the relative isolation of NORM waste from the general public for a variety of possible disposal options. As degree of isolation increases so does the capability for disposing of higher radium concentrations. Currently most oilfield NORM waste is stored at production sites awaiting disposal in specially designated and permitted landfills, disposal wells, or injection wells. Figure Disposal alternatives for NORM wastes. Disposal of more concentrated wastes requires greater isolation of waste from the general public. Modified from American Petroleum Institute (1992). Reprinted courtesy of the American Petroleum Institute-based on original API figure, modified by U.S. Geological Survey.

\section{(4)RECOMMENDATIONS:}

1-Waste of activities and processes or its ashes which retain the properties of hazardous substances and have no subsequent original or alternative uses, like clinical waste from medical treatments or the waste resulting from the manufacture of any pharmaceutical products, drugs, organic solvents, printing fluid, dyes and painting materials.

2- Those engaged in the production or circulation of hazardous materials, either in gas, liquid or solid form, are held to take all precautions to ensure that no environmental damage shall occur. The owner of an establishment whose activities produce hazardous waste pursuant to the provisions of this Law shall be held to keep a register of such waste indicating the method of disposing thereof, and the agencies contracted with to receive the hazardous waste. The executive regulations shall determine the data to be recorded in the said register and the EEAA shall be responsible for following up the register to ensure its conformity with the facts.
3- All organizations undertaking activities in the field of exploration, drilling, extraction and production of crude oil, its refining and processing shall observe the regulations and procedures set forth in the Law and its executive regulations which are derived from principles governing the international petroleum industry as provided by the competent administrative authority.

4- The management of hazardous wastes shall be subject to the following rules and procedures:

1- Engendering Hazardous Waste :

The establishment which engenders hazardous waste shall be held to do the following:

A- Try hard to reduce the rate at which such waste is produced, both quantitatively and qualitatively, by developing the technology used, employing clean technology and selecting alternatives for the primary product or the raw material which are less harmful to the environment and public health.

B- Categorize the waste produced, in terms of both quantity and quality, and register same.

C-Establish and operate units to treat waste at source, provided the EEAA approves the treatment system as well as the technical specifications of these units and their operational programs. In case of difficulty of treatment or disposal of hazardous waste at source, the establishment producing such waste shall be held to collect and transport it to the disposal sites determined by the local authorities and the competent administrative and environmental bodies. The displacement of such waste shall be subject to all the conditions and provisions prescribed in this respect by these Executive Regulations . 


\section{4-2-Stage of Collecting and Storing} Hazardous Waste:

- Determine specific locations for the storage of hazardous waste meeting safety conditions to prevent the occurrence of any harm to the public or to those persons exposed to such waste.

- Store hazardous waste in special containers made of a solid, non-porous, leak-proof material. These containers are to be hermetically sealed and their capacity must be commensurate with the quantity of hazardous waste stored therein or conform to the standards set for the storage of such waste according to type .

- Place a clear sign on the hazardous waste containers indicating their contents and warning of the dangers which may result from handling them imprudently.

D-Lay down a schedule for the collection of hazardous waste so that it is not left for long periods in the storage containers.

E-Producers of hazardous waste shall be held to provide the above-mentioned containers, wash them after each use and not place them in public places.

5- Stage of Treatment and Disposal of Hazardous Waste :

A- The sites selected to house utilities for the treatment and disposal of hazardous waste shall lie at a distance of at least three kilometres from populated and residential areas, and shall be held to meet the conditions and provide the equipment and installations set forth below :

1- The area of the site must be Proportionate to the quantity of hazardous waste so that such waste does not remain in storage for extended periods.

2-The site shall be encircled with a brick wall standing at least 2.5 meters high.
3-The site shall be provided with more than one gate of suitable width, allowing the easy entry of trucks transporting hazardous waste.

4- The site shall be provided with a water source and W.C. facilities.

5- The site shall be provided with all the protection and safety requirements prescribed in labour and vocational health laws, as well as with a telephone line.

6- The site shall be provided with all the mechanical equipment which can facilitate the work process.

7- The site shall be provided with warehouses equipped to preserve hazardous waste pending its treatment and disposal. Equipment shall differ according to the type of hazardous waste received by each utility.

8- The utility shall be provided with an incinerator for burning certain type of hazardous waste.

9- The utility shall be provided with the necessary equipment and installations for sorting and classifying certain types of hazardous waste with the intention of reutilizing and recycling them.

10-The site shall have a sanitary ditch of an adequate capacity for burying the incinerated remains.

C- Processes for the treatment of hazardous waste which cannot be reutilized and recycled shall be carried out within the following framework:

1- Injecting hazardous waste amenable to pumping into salt mines, wells and natural reservoirs in areas far from residential and populated areas.

2- Burying hazardous waste in pits specially prepared for this purpose and isolated from the other components of the environmental system. 
3- Treating hazardous waste biologically by using certain types of living micro-organisms to bring about its decomposition.

4- Treating hazardous waste physically or chemically by evaporation, dilution,

5- calcification, assimilation, sedimentation, etc.

6- Incineration in special incinerators designed to prevent the emission of gases and fumes into the surrounding environment.

7- Permanent storage (such as placing hazardous waste containers inside a mine).

D- Taking all procedures which guarantee limiting and reducing the production of hazardous waste through:

1- Developing and generalizing the use Of clean technology.

2- Developing suitable systems for the Management of hazardous waste.

\section{REFERENCES:}

1. Jonkers G, Hartog FA, Knaepen WAI, Lancée PFJ, Characterization of NORM in Oil \& Gas Production (E\&P) Industry, International Symposium on Radiological Problems with Natural Radioactivity in the Non-Nuclear Industry, Amsterdam, The Netherlands, September 1997.

2. NRPB, NORM in the Oil and Gas Industries, Radiation at Work Series (1999).

3. IAEA, Radiation Protection and the Management of Radioactive Waste in the Oil and Gas Industry, Safety Series No 34 (2003) ISBN 920-114003-7.

4. IAEA, Extent of Environmental Contamination by Naturally Occurring Radioactive Material (NORM) and Technological Options for Mitigation, Technical Reports Series No 419 (2003) ISBN 92-0-112503-8.

5. Bird AF, Rosser HR, Worrall ME, Mously KA, Fageeha OI, Technologically Enhanced Naturally Occurring Radioactive Material Associated with Sulfate Reducing Bacteria Biofilms in Large Seawater Injection System, Society of Petroleum Engineers, Conference on Health, Safety \& Environment in Oil and Gas Exploration and
Production, Kuala Lumpur, Malaysia, March 2003, SPE 73959.

6. American Petroleum Institute, Bulletin on Management of Naturally Occurring Radioactive Materials (NORM) in Oil and Gas Production, API Bulletin E2, Second Edition, April 2006.

7-Al-Masri M. S., Suman H., "NORM waste management in the oil and gas Industry" The Syrian experience, Atomic Energy Commission of Syria (AECS), (2010). Avwiri, G.O., Osimobi, J.C and Agbalagba, E.O. "Evaluation of 8-Radiation Hazard Indices and Excess Lifetime Cancer Risk Due to Natural Radioactivity in soil profile of Udi and Ezeagu Local Government Areas of Enugu State, Nigeria", J. of Environmental and Earth Sciences, 1, 1 - 10, (2012).

9-Bou-Rabee F., Al-Zamel A.Z., Al-Fares R.A., and Bem H. "Technologically enhanced naturally occurring radioactive materials in the oil industry (TENORM)". A review. Nukleonica, 54 (1), 3-9 (2009).

10-EPA. "Edition of the Drinking Water Standards and Health Advisories", EPA 822-R06-013, Washington DC (2006). 
11-ESR. "Naturally Occurring Radioactive Material (NORM)".ESREnvironmental Consulting, LLC, (2011).

12-Jamal A. Zaidan, "Natural Occurring Radioactive Materials (NORM) in the oil and gas industry", Journal of Petroleum Researches \& Studies, No.1, (2010).

13-Michalik B. Juhasz L. and Ugron A., "Surveying programme of the NORM situation of the Hungarian waterworks", EU- NORM 1st International Symposium, Estonia, (2012).

14-Sheldon Landsberger, C. Brabec , B. Canion , J. Hashem , C. Lua, D. Millsap and G. George "Determination of 226Ra, 228Ra and 210Pb in NORM products from oil and gas exploration: Problems in activity Underestimation due to the presence of metals and self-absorption of Photons" Journal of Environmental Radioactivity (2013).

15-Vasilyev A., Onishchenko A. and Zhukovsky M. "Building materials as a Dominant radon source in modern buildings" EU- NORM 1st International Symposium, Estonia, (2012).

16-Doyi, David Kofi Essumang, Samuel Dampareand Eric Tetteh Glover (2015) Reviews of Environmental Contamination and Toxicology, Volume 238, pp 107-119.

17-IAEA (2010) Radiation Protection and the Management of Radioactive Waste in the Oil and Gas Industry Training Course Series No. 40

18-Morgan, W. F. and Bair, W. J. (2013). Issues in low dose radiation biology: the controversy continues. A perspective. RadiatRes, 179, 501-510 19-IAOGP, 2016, Guidelines forthe Management of Naturally Occurring Radioactive Material (NORM) In the Oil \&Gas Industry. Report No. 412. DesoukyO.S, Ding N. and Zhou G. (2015)
Targeted and non-targeted effects ofionizingradiation. J. of Rad Res and ApplSci, 8, 247 - 254.

20-Wang, S. and Landsberger, S. (2016) MCNP modeling of NORM dosimetry in the oil and gas industry. J. Radioanal. Nucl. Chem, 309(1), 367371.

21-Desouky O. S. and Morsi T. M. (2018) Evaluation the Annual Effective Dose of the NORM Decontamination Workers during Cleaning the Oil and Gas Equipment. Arab J. Nucl. Sci. \& Applic., 51 (4), 44-50.

22- IAOGP (The International Association of Oil

\& Gas Producers) (2008) September. Guidelines forthe Management of Naturally Occurring Radioactive Material (NORM) In the Oil \&Gas Industry. Report No. 412.

23-UNSCEAR (United Nations Scientific Committee on the effects of Atomic Radiation) (2000) Sources and Effects of Ionizing Radiation. Report to General Assembly. Exposures from natural radiation sources. Annex B, United Nations, New York

24- Avwiri, G.O., Osimobi, J.C and Agbalagba, E.O. "Evaluation of Radiation Hazard Indices and Excess Lifetime Cancer Risk Due to Natural Radioactivity in soil profile of Udi and Ezeagu Local Government Areas of Enugu State, Nigeria", J. of Environmental and Earth Sciences, 1, 1 - 10, (2012).

25- Baixeras, C., Erlandsson, B., Font, L., Jonsson, G. "Radon emanation from soil samples", J. of Radiat. Meas., 34, 441443 (2001).

26- Betti, M., Aldave de las Heras, Janssens A., Henrich E., Hunter G., 
Gerchikov M., Dutton M., Van Weers A.W., Nielsen S., Simmonds J., Bexon A., and Sazykina T., "Results of the European Commission Marina II study: part II--effects of discharges of naturally occurring radioactive material", J. of Environmental Radioactivity, 74 (1-3), 255-277, (2004).

27- Bou-Rabee F., Al-Zamel A.Z., Al-Fares R.A., and Bem $H$. "Technologically enhanced naturally occurring radioactive materials in the oil industry (TENORM)". A review. Nukleonica, 54 (1), 3-9 (2009).
28- Brounstein, R. and Johnson, W.H. Influence of fiber-reinforced concrete on radon concentrations. J. of Materials in Civil Eng., 16 (6) 646-649 (2004).

29- Chang, W.P., C.C. Chan and J.D. Wang. "Co60 contamination in recycled steel resulting in elevated civilian radiation doses: causes and challenges", Health Phys. 73(3), 465-472 (1997). 


\section{تاثير المواد المشعة طبيعيا المنتجة تكنولوجيا من صناعة البترول والغاز الطبيعي على البيئة

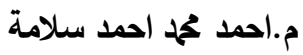 \\ قسم الهنسة البيئية بكلية الهنسة ، جامعة حلوانة}

إن أهم مصادر الإشعاع الطبيعي في صناعة النفط والثاز هي النويدات المشعة الناتجة عن سلاسل الاضمحلال الطبيعية لكل

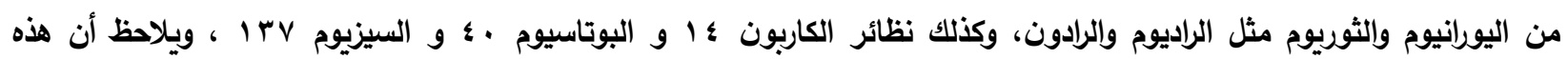

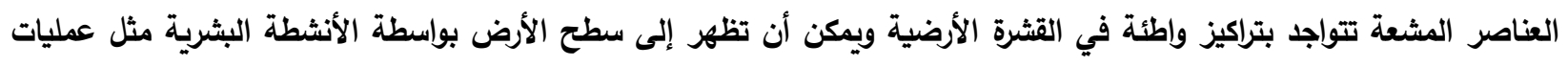

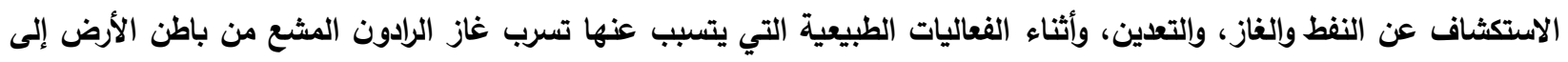
الهواء الجوي ، أو تحرر هذا الغاز من المياه الجوفية. 